Orikhovska A, Fedorenko S, Kolyushko K. Modern approaches to physical therapy of persons after total hip endoprosthesics. Theory and Methods of Physical education and sports. 2020; 1: 81-86 DOI: $10.32652 /$ tmfvs.2020.1.81-86
Оріховська А, Федоренко С, Колиушко К. Сучасні підходи фізичної терапії осіб після тотального ендопротезування кульшового суглоба. Теорія і методика фрізичного виховання і спорту. 2020; 1: 81-86

DOI: $10.32652 /$ tmfvs.2020.1.81-86

\title{
СУЧАСНІ ПІДХОДИ ФІЗИЧНОЇ ТЕРАПІЇ ОСІБ ПІСЛЯ ТОТАЛЬНОГО ЕНДОПРОТЕЗУВАННЯ КУЛЬШОВОГО СУГЛОБА
}

\section{Анна Оріховська, Серхій Федоренко, Катерина Колиушко}

Національний університет фізичного виховання і спорту України, Київ, Україна

\begin{abstract}
Анотація. Тотальне ендопротезування кульшового суглоба є одним із сучасних та ефективних методів хірургічного лікування тяжких захворювань та ушкоджень, яке сьогодні перейшло з категорії унікальних операцій в категорію звичайних планових хірургічних втручань. Мета. Висвітлити роль фрізичної терапії у відновлювальному процесі осіб після тотального ендопротезування кульшового суглоба, проаналізувати та порівняти сучасні зарубіжні і вітчизняні підходи до фізичної терапії в осіб після даного оперативного втручання. Методи. Теоретичний аналіз та узагальнення даних науково-методичної літератури. Результати. Незважаючи на технічну складність, тотальна артропластика стегна сьогодні $€$ одним з найпоширеніших та найуспішніших ортопедичних втручань у світі і «золотим стандартом» лікування. Фізична терапія після тотального ендопротезування $є$ невід'ємною складовою відновного процесу і входить до стандартів лікування патологій кульшового суглоба та оперативного лікування зокрема. Ї̈ метою є максимальна функціональність та незалежність пацієнта, а також мінімізація ускладнень та покращення якості життя.

Недивлячись на постійне удосконалення процедури ендопротезування та появу сучасних якісних матеріалів ендопротезів, великий досвід ортопедів-травматологів, спеціалістів з відновлення і реабілітації, близько 12 \% пацієнтів мають різного роду ускладнення після оперативного втручання, що у більшості випадків призводить до стійкої втрати працездатності та інвалідності. Значна частина фрахівців вважає саме недостатньо відпрацьований алгоритм ведення пацієнта, зокрема і його відновлення, однією з основних причини розвитку ускладнень та уповільнення процесу відновлення.
\end{abstract}

Алгоритм фрізичної терапії в осіб після тотального ендопротезування кульшового суглоба, розроблено відповідно до сучасних підходів, заснованих на базі доказової медицини. Він $є$ запорукою максимально успішного та швидкого повернення пацієнта до повноцінного життя.

Ключові слова: ендопротезування кульшового суглоба, фрізична терапія, алгоритм фрізичної терапії, відновний процес, якість життя.

\section{Anna Orikhovska, Serhii Fedorenko, Kateryna Kolyushko MODERN APPROACHES TO PHYSICAL THERAPY OF PERSONS AFTER TOTAL HIP ENDOPROSTHESICS}

\begin{abstract}
Total hip arthroplasty is one of the modern and effective methods of surgical treatment of serious diseases and injuries, which today has moved from the category of unique operations to that of common planned surgical interventions. Objective. To highlight the role of physical therapy in the recovery process of persons after total hip arthroplasty, to analyze and compare modern foreign and domestic approaches to physical therapy of persons after this surgery. Methods. Theoretical analysis and generalization of data of scientific and methodical literature. Results. Despite technical complexity, total hip arthroplasty is today one of the most common and successful orthopedic interventions in the world and the "gold standard» of treatment. Physical therapy after total arthroplasty is an integral part of the recovery process and is included in the standards of treating pathologies of the hip joint and surgical treatment in particular. Its goal is maximum functionality and independence of the patient, as well as minimizing complications and improving the quality of life. Despite constant improvement of the endoprosthesis procedure and the appearance of modern high-quality endoprosthesis materials, extensive experience of orthopedic traumatologists, specialists in recovery and rehabilitation, about $12 \%$ of patients have various complications after surgery, which in most cases leads to permanent disability. Many experts believe that the insufficiently developed algorithm of patient management, including his recovery, is one of the main reasons for the development of complications and slowing down the recovery process.

Algorithm of physical therapy of persons after total hip arthroplasty has been developed in accordance with modern approaches based on evidence-based medicine. It is the key to the most successful and rapid return of the patient to productive life.
\end{abstract}

Keywords: hip arthroplasty, physical therapy, physical therapy algorithm, recovery process, life quality. 
Вступ. Захворювання та пошкодження кульшового суглоба є найбільш поширеною патологією опорно-рухового апарату і має стійку тенденцію до зростання. Низька ефективність консервативної терапії та високий відсоток інвалідності одна $з$ основних проблем лікування дистрофічнодегенеративних захворювань та пошкоджень кульшового суглоба. Проте, завдяки досягненням сучасної медицини, ряд проблем сьогодні можна вирішити шляхом проведення процедури тотального ендопротезування кульшового суглоба (ТЕП КС).

Недивлячись на постійне удосконалення процедури ендопротезування, великий досвід ортопедівтравматологів свідчить, що пацієнти мають різного роду ускладнення після оперативного втручання, що у більшості випадків призводить до стійкої втрати працездатності та інвалідності. Значна частина фахівців вважає саме недостатньо відпрацьований алгоритм ведення пацієнта, зокрема і його відновлення, однією з основних причини розвитку ускладнень та уповільнення процесу відновлення [2, 3].

Адекватна і своєчасна фізична терапія (ФT) після ТЕП КС має надзвичайно важливе значення для профілактики ускладнень, прискорення процесу відновлення пацієнта та повернення його до активного життя [14].

Вагомим аргументом, який зумовлюе необхідність розробки максимально ефективного та чіткого алгоритму ФТ в осіб після ТЕП КС, є поступовий перехід до страхової медицини та скорочення термінів перебування хворих у стаціонарах, що продиктовано економічними аспектами.

Проте, в наявній вітчизняній та зарубіжній літературі наразі не існує загальноприйнятого систематизованого та стандартизованого протоколу (алгоритму) ФТ у пацієнтів після ТЕП КС, розписаного за фазами (етапами) реабілітаційного процесу. Більше того, існують певні відмінності в термінології, тривалості періодів реабілітаційного втручання, методах, які застосовуються у ФТ, що імовірно продиктовано дещо різними підходами до лікування та реабілітації, тривалістю перебування пацієнта у стаціонарі і головне, - відсутністю єдиного уніфікованого протоколу фізіотерапевтичного втручання як в Україні, так і за кордоном [7].

Мета дослідження - проаналізувати та порівняти сучасні підходи фізичної терапії в осіб після тотального ендопротезування кульшового суглоба, які застосовуються в Україні і за кордоном.

Методи дослідження: теоретичний аналіз й узагальнення даних науково-методичної літератури.

Результати дослідження та їх обговорення. ФТ після ТЕП КС входить до всіх міжнародних та національних стандартів клінічного менеджменту хворих, що потребують ендопротезування кульшового суглоба, і становить основу протоколу (алгоритму) відновного лікування (реабілітаційного втручання) [4, 7].
Фізична терапія спрямована на покращення активного діапазону рухів, зміцнення м'язів стегна, стабілізації кульшового суглоба, а також відновлення нейро-м'язової координації, балансу та пропріоцепції [1, 4, 16]. За сучасними уявленнями, однією з основних цілей ФТ та невід'ємною її складовою має бути не лише моторне відновлення оперованої нижньої кінцівки, а й, перш за все, відновлення фізіологічного стереотипу руху відносно щоденної діяльності пацієнта, його активності та участі [20].

Світовими товариствами з ортопедичної реабілітації визнано, що реабілітаційне втручання має проводитися 3 позицій Міжнародної класифікації функціонування, обмежень життєдіяльності та здоров'я (МКФ), а тому базуватися на таких ключових принципах: проблемно-орієнтрований підхід та мультидисциплінарний підхід, а також постановка реабілітаційних цілей у специфічному SMART-форматі [8, 20].

Сучасний процес (за МКФ) ФТ в осіб після ТЕП КС включає:

- оцінку стану та загальної ситуації пацієнта відповідно МКФ;

- визначення списку проблем;

- постановку реабілітаційних цілей;

- вибір методів і засобів терапевтичного втручання та його реалізацію;

- оцінку результату - ефективності втручання [5, 8, 20].

Взаємодія пацієнта та медичних і реабілітаційних служб на сьогодні базується на специфічній прогресивній біопсихосоціальній моделі або моделі «якості життя», яка розглядає не обмеження (інвалідність), а власне особливості функціонування у соціумі - активність і участь за МКФ, де беруться до уваги також контекстні фактори [5]. МКФ робить акцент на функції, а не на стані чи захворюванні й охоплює всі аспекти здоров'я людини та деякі складові благополуччя, пов'язані зі здоров'ям. Функціонування та втрата працездатності описані в МКФ з точки зору динамічної взаємодії між станом здоров'я, особистісними факторами та навколишнім середовищем [20].

Фізична терапія після ТЕП КС розглядається 3 позицій всіх компонентів МКФ. Проте кінцева iii мета спрямована саме на компонент «участь». За МКФ, «участь» - це участь у життєвій ситуації. Відповідно, обмеження участі - це проблеми, пов'язані із залученням до життєвих ситуацій: набуття знань, комунікація, мобільність, піклування про себе, побутове життя, міжособистісні відносини, щоденні завдання [5, 13$]$.

Важливим аспектом терапевтичного втручання після ТЕП є постановка реабілітаційних цілей, які є ключовим предиктором ефективності ФТ після даного виду оперативного втручання. Дані цілі можуть бути переоцінені після будь-яких змін від початкової оцінки. Реабілітаційна ціль ставиться лише разом $з$ пацієнтом та витікає лише з його по- 
треб, тобто його запиту. Під час роботи з пацієнтом визначають глобальну, довгострокові і короткострокові цілі. [13].

Глобальну ціль - кінцеву мету втручання (мету пацієнта) - розділяють на довгострокові цілі, на виконання яких ставлять певні часові рамки (наприклад, місяць). Короткострокові цілі у SMARTформаті дозволяють бачити прогрес i керувати процесом під час терапевтичного втручання в осіб після ендопротезування кульшовго суглоба.

Щодо мультидисциплінарного підходу, згідно 3 рекомендаціями європейських, американських та вітчизняних реабілітаційних співтовариств, а також провідних ортопедичних клінік, до команди, що забезпечує реабілітаційне втручання, мають входити: консультуючий хірург, реабілітаційна команда (лікар фізичної та реабілітаційної медицини, фізичний терапевт та ерготерапевт), середній та молодший медичний персонал, психолог, соціальний працівник, дієтолог та інші спеціалісти (за необхідності). Центральною фігурою є пацієнт та його найближче оточення. 3 точки зору мультидисциплінарного підходу, пацієнт є не лише частиною, а центральною діючою особою [8].

Саме мультидисциплінарний підхід вважається найбільш оптимальним для реабілітаційного менеджменту осіб після ТЕП КС, що дозволяє не лише максимально ефективно і швидко відновити пацієнта, а й знизити показники повторної госпіталізації, клінічних ускладнень та передчасної ревізійної операції [8, 12].

Щодо безпосереднього втручання ФТ, в сучасній літературі наразі не існує єдиного протоколу після тотальної заміни стегна, розписаної по фазах та етапах реабілітаційного процесу. Кожна клініка розробляє свої протокол та алгоритм, керуючись загальними рекомендаціями клінічних протоколів ведення пацієнтів після даного хірургічного втручання. Проте нині провідні асоціації з ФТ працюють над створенням практичних рекомендацій до управління ортопедичною фізичною терапією (в тому числі для менеджменту пацієнтів після ТЕП КС), заснованих на основі доказової медицини та МКФ, які матимуть статус національних [9, 12].

У даній статті було опрацьовано протоколи зарубіжних ортопедичних клінік, а також деякі протоколи та алгоритми, розроблені вітчизняними спеціалістами, і виявлено деякі відмінності як у термінології, так і в тривалості періодів реабілітаційного втручання, що імовірно продиктовані дещо різними підходами до лікування та реабілітації, тривалості перебування пацієнта у стаціонарі і головне, відсутністю єдиного уніфікованого протоколу фізіотерапевтичного втручання як в Україні, так і за її межами. Наприклад, що стосується термінів госпіталізації після ТЕП КС, вони кардинально відрізняються в різних країнах. Так, за результатами Глобального ортопедичного реєстру (GLORY), загальна тривалість пе- ребування в стаціонарі після ТЕП становить три доби в США, дев'ять - у Великій Британії, одинадцять - у Німеччині, та аж тридцять - у Японії [11]. Що стосується України, тут пацієнт знаходиться в хірургічному стаціонарі в середньому чотири-сім діб [1, 4].

Глобально і українські, і зарубіжні спеціалісти виділяють передопераційну та післяопераційну реабілітацію (ФТ) пацієнтів, які потребують ендопротезування кульшового суглоба. Післяопераційне реабілітаційне втручання вони традиційно поділяють на стаціонарний (inpatient rehabilitation) та амбулаторний етапи (outpatient rehabilitation) [1, 10, 18, 19].

Стаціонарне реабілітаційне втручання (стаціонарна ФТ) проводиться в реабілітаційному стаціонарі або спеціалізованому відділенні лікувального закладу. Амбулаторна реабілітація (амбулаторна ФТ) починається після виписки пацієнта і проводиться або в спеціалізованій реабілітаційній клініці (центрі), або вдома у пацієнта $[5,6]$. Щодо наступних етапів ФТ, то у ході вивчення літературних джерел подальший поділ на етапи терапевтичного втручання не був таким однозначним.

У вітчизняних джерелах пропонується такий алгоритм: після оперативного втручання у рамках стаціонарного етапу реабілітації починається ранній післяопераційний період - перший етап реабілітації. Його тривалість залежить від складності оперативного втручання та наявності ускладнень (у середньому від двох-чотирьох до семи-чотирнадцяти діб). Частина його проходить ще у хірургічному стаціонарі (чотири-сім діб). Далі хворий може поступити у реабілітаційний стаціонар і продовжити стаціонарний етап реабілітації. Після виписки розпочинається амбулаторний етап, який може проходити у поліклініці (спеціалізованому центрі реабілітації) або в санаторії (рання санаторна реабілітація), і триває з моменту виписки до трьох-шести місяців після оперативного втручання, включаючи пізній та віддалений післяопераційний періоди (другий і третій етапи). Після трьох-шести місяців 3 моменту операції, за умови збереження функціональних обмежень, може бути розпочато віддалений етап реабілітації (четвертий етап), а за ним санаторно-курортне лікування $[1,4]$.

Зарубіжні спеціалісти замість терміна «етап реабілітації» застосовують термін «фаза реабілітаційного втручання». До того ж вони розглядають реабілітацію, як сервісну послугу: пацієнт може отримати стаціонарну або амбулаторну програму терапевтичного втручання [1, 17, 18].

За кордоном, починаючи 3 першого дня після оперативного втручання, пацієнт входить в першу фазу реабілітації - фазу захисту, яка триває до моменту виписки - в середньому п'ять-сім діб (тривалість перебування у стаціонарі залежить не лише від стану пацієнта, а й від протоколів клініки, де було проведено оперативне втручання), 
основним змістом є запобігання виникненню ранніх післяопераційних ускладнень. За нею починається друга фаза - перехідний етап - яка триває 3 восьмого дня (з моменту виписки) до четвертого-п'ятого тижня включно (приблизно місяцьпівтора після операції). Проміжна - третя фаза втручання - починається 3 п'ятого-шостого тижня після операції і триває до восьмого-дев'ятого тижня включно (до двох місяців після операції). Основними цілями перехідної та проміжної фаз є поступове відновлення всіх функцій кульшового суглоба, відмова від допоміжного засобу пересування та освоєння правильного стереотипу ходьби з урахуванням біомеханіки штучного суглоба. Через 10-12 тижнів (два 3 половиною-три місяці) після хірургічного втручання починається четверта фаза - розширена, яка спрямована на повне функціональне відновлення пацієнта та покращення його якості життя $[10,18]$.

Деякі американські протоколи виділяють п'яту фазу - повернення до високого рівня функціональної активності (або інша назва - фаза специфічного спортивного тренування), яка починається через три місяці після операції і триває до повного відновлення пацієнта [18].

У зв'язку з необхідністю дотримання певних обмежень протягом майже трьох місяців після операції варто чітко розділити амбулаторний етап на ранній (перші три місяці) та пізній (після трьох місяців), який в зарубіжній літературі визначається як період високої функціональної активності.

Незважаючи на відмінності у термінології та термінах тривалості етапів (фаз) терапевтичного втручання, і вітчизняні і зарубіжні протоколи описують їх однаково: кожен етап (фаза) має мету, терапевтичні цілі та чітко визначені критерії досягнення цих цілей та переходу на наступний етап. Також відповідними зарубіжним є вітчизняні загальні рекомендації до запобігання вивиху ендопротеза.

Важливим етапом, на який звертають увагу спеціалісти, є передопераційна реабілітація («преабілітація»), метою якої є підготовка пацієнта до хірургічного втручання та до функціонування після нього: навчання пацієнта правил запобігання вивиху, базового комплексу терапевтичних вправ, які він буде виконувати у перші дні після операції, ходьби за допомогою допоміжних засобів (милиці, ходунки) [1, 10, 19]. До передопераційного планування можна віднести і планування простору вдома, що є надзвичайно важливим на всіх етапах відновлення після операції, зважаючи на небезпеку падіння та вивиху ендопротеза.

Ще одним важливим моментом, на якому наголошують і вітчизняні, і зарубіжні спеціалісти, є рання мобілізація хворого, яка впливає на зменшення больового синдрому та сприяє зниженню терміну госпіталізації, а, отже, має економічно вигідний аспект [1, 16, 17].
Щодо змісту ФТ, то у доступній літературі немає даних про широке включення у програму ФТ методів фізіотерапії та масажу (хоча масаж досить часто зустрічається у підрозділі Мануальна терапія). Так, рекомендації з ФТ у передовій практиці після ТЕП КС США та Канади включають терапевтичні вправи (для зміцнення м'язів, на покращення активного діапазону рухів, баланстренування) та тренування ходьби (або так звані функціональні тренування), а також рекомендації до щоденної активності, в тому числі рекреаційної [10, 16].

Вітчизняні спеціалісти використовують модель комплексної реабілітації, що включає терапевтичні вправи, рекомендації до щоденної активності, фізіотерапію та масаж, а також механотерапію $[1,4]$.

Основним засобом ФТ в алгоритмах є фізичні вправи, які реалізуються як силові тренування для зміцнення м'язів, тренування балансу та координації, вправи на гнучкість, відпрацьовування механіки рухів та поступальної стійкості. Важливим компонентом ФТ є так звані функціональні вправи, виконання яких спрямоване на тренування рухів з повсякденної діяльності пацієнта (наприклад, для освоєння особистого догляду, проведення активного дозвілля, мобільності у простоpi) $[4,8]$.

До терапевтичного втручання також відносять мануальну терапію (терапевтичний масаж, пасивний діапазон рухів, мобілізацію (маніпуляцію) м'яких тканин), а також фізіотерапію (кріотерапія, гідротерапія, звукова терапія, електроміостимуляція тощо) [16]. Дослідження підвищення ефективності реабілітаційного процесу поєднанням терапевтичних вправ та фізіотерапії ще проводяться. Проте, за результатами дослідження Альгамрі, електроміостимуляція все ж є ефективною для збільшення сили, діапазону рухів та, як наслідок, якості життя [6].

Дискусія. Прогрес оперативних технологій зробив ТЕП КС оперативним втручанням століття. За прогнозами, протягом наступного десятиліття кількість первинних ТЕП КС істотно зросте: попит на таке оперативне втручання прогнозовано збільшиться на 174 \% до 2030 р. [15].

У ході аналізу літературних джерел було виявлено, що в професійних колах досі існують певні відмінності, особливо що стосується часових діапазонів основних етапів (фаз) відновного процесу. Також під час проведення дослідження не вдалося знайти стандартизованих протоколів та алгоритмів відновного процесу після ТЕП КС, які застосовуються на національних та міжнародному рівнях. Варто зазначити, що в основних підходах до сучасної фізичної терапії після ТЕП КС европейські, американські та українські спеціалісти все ж дотримуються одних і тих самих підходів. Алгоритм ФТ після ТЕП КС, створений на основі сучасних підходів реабілітаційної та доказової медицини, 
дасть змогу вирішити ряд питань: знизити частоту ускладнень після оперативного втручання, скоротити тривалість госпіталізації, прискорити процес відновлення та покращити якість життя людей.

Висновки. ТЕП КС є одним 3 найбільш ефективних та успішних методів лікування тяжких захворювань та ушкоджень кульшового суглоба. ФТ як основна складова відновного процесу має надзвичайно важливе значення, тому питання чітко визначеного ефективного алгоритму втручання є дуже актуальним. Значна кількість проаналізованої зарубіжної та вітчизняної літератури доводить ефективність ФТ, проте моделі втручання мають свої відмінності щодо тривалості етапів (фаз) фізіотерапевтичного втручання, а також щодо пріоритетних засобів ФТ: якщо за кордоном перевагу віддають «чистій» ФТ (терапевтичні вправи, функціональні тренування, дещо рідше мануальна терапія), то вітчизняні фахівці пропонують комплексну модель із застосуванням фізіотерапії та масажу.

Сучасними підходами успішного відновлення хворих вважають: передопераційну підготовку, ранню мобілізацію, дотримання післяопераційних обмежень та терапевтичне втручання, які, за умови їх виконання, сприяють успішному процесу відновлення хворих після ТЕП КС та якнайшвидшого повернення до звичайного способу життя.

Перспективи подальших досліджень передбачають створення алгоритму фізичної терапії осіб після тотального ендопротезування кульшового суглоба на основі сучасних загальновизнаних підходів відновного втручання, заснованих на базі доказової медицини.

Конфлікт інтересів. Автори заявлять, що відсутній будь-який конфлікт інтересів.

\section{Література}

1. Бабова ІК, Торчинський ВП, Біла II, Майко ВМ. Алгоритм реабілітації хворих, що потребують ендопротезування кульшового суглоба. Вісник ортопедії, травматології та протезування.2010; 2: 30-35.

2. Васильчишин ЯМ. Удосконалена технологія ендопротезування кульшового суглоба. Буковинський медичний вісник. 2014; 4 (72):7-12.

3. Гайко ГВ, Поляченко ЮВ, Рибачук ОІ. Стан та перспективи розвитку ендопротезування суглобів в Україні. Вісник ортопедії, травматології та протезування. 2000; 2(27):71-72.

4. Глиняна О, Попадюха Ю. Алгоритм реабілітації після первинного ендопротезування кульшового суглоба. Психологія та педагогіка. 2011; 8: 30-32.

5. Міжнародна класифікація функціонування, обмеження життєдіяльності і здоров'я: МКФ (переклад українською мовою). Всесвітня організація охорони здоров'я, Женева, 2001.

6. Alghamry S. Effectiveness of physical rehabilitation and electro-stimulation after hip joint replacement surgery. World Journal of Sport Sciences. 2011;4(1):41.

7. Aprato A, Baroni $C$ and Massè $C$. Rehabilitation after total hip arthroplasty: Is there an evidence? Phys Med Rehabil Res. 2018; 3(4): 1-2.

8. Bach JA, Leskovan JJ, Scharschmidt T, Boulger C, Papadimos TJ, Russell S, Bahner DP et al. The right team at the right time - Multidisciplinary approach to multi-trauma patient with orthopedic injuries. Int J Crit Illn Inj Sci. 2017 Mar; 7(1): 32-7.

9. Beswick A, Wylde V, Artz N, Lenguerrand N, Jepson P, Sackley C, et al. How close are we to evidence-based comprehensive rehabilitation for patienrs receiving total hip and knee arthroplasty? A programme of systematic reviews and feasibility studies. Orthopaedic Proceedings. 2018 Apr, 5; 100(3): 32-7.

10. Brian J. White. Post Operative Total Hip Replacement Protocol. Howard Head Sport Medicine Centers. 2015.

11. Eulenburg C, Rahlf A-L, Kutasov A, Zech A. Agreements and disagreements in exercise therapy prescriptions after hip replacement among rehabilitation professionals: a multicenter survey. BMC Musculoskelet Disord. 2015; 16: 185 .

12. Guimarães Barros AA, Cardoso Mendes CH, Frois Temponi E, Costa L, et al. Efficacy evaluation of a protocol for safe hip surgery (total hip arthroplasty). Rev Bras Ortop. 2017; 52(1): 29-33.

13. Hoang-Kim AM. Functional outcomes in the aged with hip fracture: a systematic review of randomized clinical trials.Institute of Medical Sciences University of Toronto. Master's of Science. 2009.

14. Krastanova MS, Ilieva EM, Valcheva DE. Rehabilitation of patients with hip joint arthroplasty. Folia Medica.2017;59(2):217-221.

15. Kurtz SM, Ong K, Lau E, Mowat F, Halpern M. Projections of primary and revision hip and knee arthroplasty in the United States from 2005 to 2030. J Bone Joint Surg Am. 2007;89(4):780-785.

16. Physical Therapy Association. Guide to Physical Therapist Practice. second edition. American Physical Therapy Association. Phys Ther. 2001.

17. Physiotherapy Rehabilitation After Total Knee or Hip Replacement. An Evidence-Based Analysis. Ont Health Technol Assess Ser. 2005; 5(8): 1-91.

18. Rehabilitation Protocol: Total Hip Arthroplasty (THA). Lahey Hospital \& Medical Center. 2014.

19. Total Hip Arthroplasty (Direct Anterior Approach) Rehab Protocol. Texas Orthopaedic Surgical Associates. 2013.

20. Towards a Common Language for Functioning, Disability and Health. ICF. World Health Organization, Geneva 2002. 


\section{Literature}

1. Babova IK, Torchynskyi VP, Bila II., Mayko VM. Algorithm for rehabilitation of patients in need of hip arthroplasty. Visnyk ortopedii, travmatolohii ta protezuvannia.2010; 2: 30-35.

2. Vasylchyshyn IM. Improved technology of hip arthroplasty. Bukovynskyi medychnyi visnyk. $2014 ; 4$ (72):7-12.

3. Hayko HV, Poliachenko IV, Rybachuk OI. Status and prospects of joint arthroplasty development in Ukraine. Visnyk ortopedii, travmatolohii ta protezuvannia. 2000; 2(27):71-72.

4. Hlyniana O, Popadiukha I. Rehabilitation algorithm after primary hip arthroplasty. Psykholohiia ta pedahohika. 2011; 8: 30-32. 2001.

5. International classification of functioning, restriction of life and health: ICF. World Health Organization, Geneva,

6. Alghamry S. Effectiveness of physical rehabilitation and electro-stimulation after hip joint replacement surgery. World Journal of Sport Sciences. 2011;4(1):41.

7. Aprato A, Baroni $C$ and Massè $C$. Rehabilitation after total hip arthroplasty: Is there an evidence? Phys Med Rehabil Res. 2018; 3(4): 1-2.

8. Bach JA, Leskovan JJ, Scharschmidt T, Boulger C, Papadimos TJ, Russell S, Bahner DP et al. The right team at the right time - Multidisciplinary approach to multi-trauma patient with orthopedic injuries. Int J Crit Illn Inj Sci. 2017 Mar; 7(1): 32-7.

9. Beswick A, Wylde V, Artz N, Lenguerrand N, Jepson P, Sackley C, et al. How close are we to evidence-based comprehensive rehabilitation for patienrs receiving total hip and knee arthroplasty? A programme of systematic reviews and feasibility studies. Orthopaedic Proceedings. 2018 Apr, 5; 100(3): 32-7.

10. Brian J. White. Post Operative Total Hip Replacement Protocol. Howard Head Sport Medicine Centers. 2015.

11. Eulenburg C, Rahlf A-L, Kutasov A, Zech A. Agreements and disagreements in exercise therapy prescriptions after hip replacement among rehabilitation professionals: a multicenter survey. BMC Musculoskelet Disord. 2015; 16: 185.

12. Guimarães Barros AA, Cardoso Mendes CH, Frois Temponi E, Costa L, et al. Efficacy evaluation of a protocol for safe hip surgery (total hip arthroplasty). Rev Bras Ortop. 2017; 52(1): 29-33.

13. Hoang-Kim AM. Functional outcomes in the aged with hip fracture: a systematic review of randomized clinical trials. Institute of Medical Sciences University of Toronto. Master's of Science. 2009.

14. Krastanova MS, Ilieva EM, Valcheva DE. Rehabilitation of patients with hip joint arthroplasty. Folia Medica.2017;59(2):217-221.

15. Kurtz SM, Ong K, Lau E, Mowat F, Halpern M. Projections of primary and revision hip and knee arthroplasty in the United States from 2005 to 2030. J Bone Joint Surg Am. 2007;89(4):780-785.

16. Physical Therapy Association. Guide to Physical Therapist Practice. second edition. American Physical Therapy Association. Phys Ther. 2001.

17. Physiotherapy Rehabilitation After Total Knee or Hip Replacement. An Evidence-Based Analysis. Ont Health Technol Assess Ser. 2005; 5(8): 1-91.

18. Rehabilitation Protocol: Total Hip Arthroplasty (THA). Lahey Hospital \& Medical Center. 2014. 2013.

19. Total Hip Arthroplasty (Direct Anterior Approach) Rehab Protocol. Texas Orthopaedic Surgical Associates.

20. Towards a Common Language for Functioning, Disability and Health. ICF. World Health Organization, Geneva 2002.

\author{
Інформація про авторів \\ Оріховська Анна Сергіївна \\ https://orcid.org /0000-0003-4742-1585 \\ anetorekhovskaya1305@gmail.com \\ Федоренко Сергій Миколайович \\ ORCID.ORG/ 0000-0002-6266-5361 \\ E-mail fesco_clinic@ukr.net \\ Колиушко Катерина Вікторівна \\ E-mail kolyushko_katya@ukr.net \\ Національний університет \\ фізичного виховання і спорту України \\ 03150, Київ, вул. Фізкультури 1,
}

\author{
Information about the authors \\ Orikhovska Anna \\ https://orcid.org /0000-0003-4742-1585 \\ anetorekhovskaya1305@gmail.com \\ Fedorenko Sergey \\ ORCID.ORG/0000-0002-6266-5361 \\ E-mail fesco_clinic@ukr.net \\ Kolyushko Kateryna \\ E-mail kolyushko_katya@ukr.net \\ National University \\ of Ukraine on Physical Education and Sport \\ 03150, Kyiv, Fizkul'tury str., 1.
}

